\title{
Comparison of Nonlinear Time Domain Site Response Analysis Subjected to Earthquake Provokes-Case Study
}

\author{
Abbas Abbaszadeh Shahri ${ }^{1, *}$, Bizhan Esfandiyari', Katayoun Behzadafshar ${ }^{3}$, Mohammad Amin $\operatorname{Vares}^{4}$ \\ ${ }^{1}$ Department of Geophysics, Islamic Azad University, Hamedan Branch, Hamedan, Iran \\ ${ }^{2}$ Department Engineering, Engineering faculty of Tehran University, Tehran, Iran \\ ${ }^{3}$ Department of Basic Sciences, Islamic Azad University, Shahr-e-Rey Branch, Tehran, Iran \\ ${ }^{4}$ Department Engineering, Islamic Azad Universty, Science and Research Branch, Tehran, Iran
}

\begin{abstract}
The present paper aims to characterize the nonlinear time domain seismic site response analysis taking into consideration geomorphological conditions, geotechnical and geophysical parameters by use of generated geotechnical based GUI computer software. In this paper a case study on ground response analysis of a seismic geotechnical site response analysis on Damghan earth dam in Semnan province of Iran during the Kahak earthquake (M15.7, 2007) after the magnitude-scaling factor is presented. For site characterization, deep site investigations have been undertaken and the nonlinearity on site response for the selected site with assumption of elastic and rigid half space bedrock by use of nonlinear standard hyperbolic model was evaluated. The modeling was implemented using the combination of several computer codes with MATLAB programming tool and their results over a number of geotechnical areas were compared to each other. The key factor in this work was to develop and use "Abbas Converter" and the present research shows its ability on site response analyses procedure.
\end{abstract}

Keywords Abbas Converter, Kahak Earthquake, Damghan Earth Dam

\section{Introduction}

Site response analysis is usually the first step of any seismic soil-structure interaction study and the problem refers to predict soil response at selected locations of the profile such at the free surface or foundation depth, resulting from the prescribed seismic excitation. On mathematics point of view, the problem is wave propagation in a continuous medium. Modeling of nonlinear soil behavior in $3 \mathrm{D}$ wave propagation exactly is extremely difficult and for this reason, the main response in the soil deposit can properly approximated with 1D or 2D vertical propagation of shear waves (Vs). There are large varieties of computer programs available for solving the $1 \mathrm{D}$ wave equation.

Nonlinear site response has discussed by Seed and Idriss (1970). However, linear theory has generally been used to estimate site response (Borcherdt, 1970; Aguirre et al., 1994). With more data being recorded in the near source areas of recent large earthquakes, it has become clear that nonlinear site response can have a major effect (Idriss, 1991; Aki, 1993; Iwasaki and Tai, 1996; Field et al., 1997, 1998; Bonilla et al., (2005). Several studies have estimated at what level of shaking one should expect a noticeable nonlinear site

\footnotetext{
* Corresponding author:

a_abbaszadeh@iauh.ac.ir (Abbas Abbaszadeh Shahri)

Published online at http://journal.sapub.org/jce

Copyright $(2012$ Scientific \& Academic Publishing. All Rights Reserved
}

response. Idriss (1991) indicates that if PGA is more than $0.4 \mathrm{~g}$ at soft soil sites, the effect will be noticeable. Midorikawa (1993) and Beresnev (2002) also estimate nonlinear site response if PGA exceeds 200gal, or peak ground velocity (PGV) exceeds $15 \mathrm{~cm} / \mathrm{s}$.

\section{Geological Setting of Semnan Province}

The portion of Alpine belt from Iran in the west to Burma in the east, seismically, is one of the most active intercontinental regions of the world. Semnan region is part of the Iranian plateau that is subjected to many tectonic activities, including active folding, faulting and volcanic eruptions. Semnan province is placed in southern flank of Alborz Mountains and north of Kavir desert of Iran, so its geology setting belongs to Alborz and central Iran structural zones. Semnan fault (passes from north of Semnan) and Attari fault (30 km east of Semnan) are two major structural features with general NE-SW trend which pass through the northern part of Semnan province. Geological data specially the comparison of geological characteristics of northern part (Alborz) and southern part (Central Iran) have demonstrated that in fact there are not contrasting differences between northern and southern parts, in other words northern parts of this province is in fact the folded margin of central Iran. However, block tectonics has caused creation of sedimentary basins in tectonic realms of these fault zones so that the 
lithology and thickness of lithostratigraphic units of the same age have some differences in both sides of these fault zones.

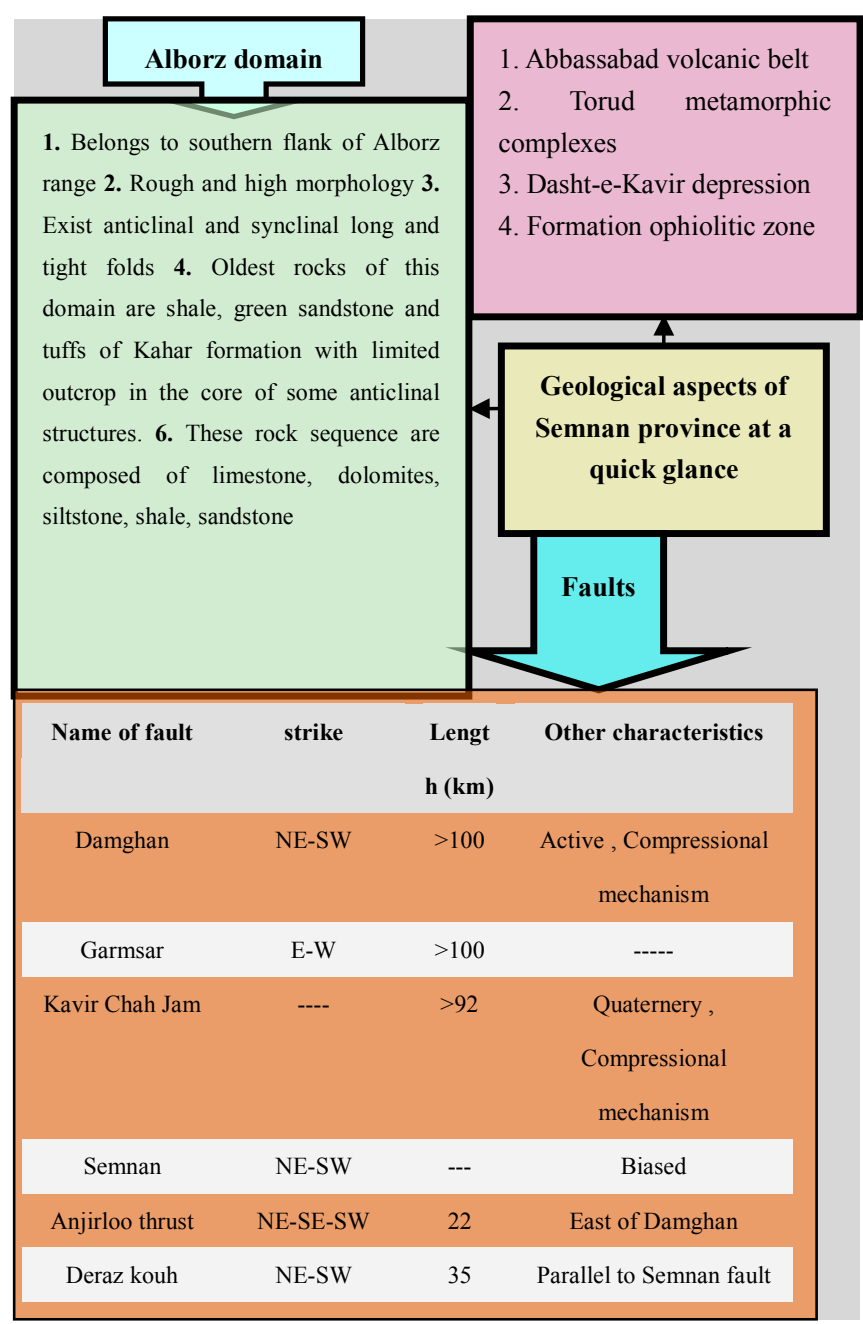

Figure 1. quick glance of geological features of Semnan province

The historical context of earthquakes in this region has been compiled by Ambraseys and Melville (2005). First-motion data indicate that these earthquakes are almost all generated by reverse slip and subsidiary strike-slip movements (Dehghani and Makris, 1983). The strike-slip component of deformation probably has a complex origin. Earthquakes are characteristically shallow, of large magnitude but are discontinuous, with long recurrence periods (Berberian 1977). Figurel shows the general geological aspects of the Semnan province.

\section{Mathematical Modeling of Nonlinear Soil Behavior}

In site response analysis, soil properties including shear modulus and cyclic soil behavior are required. Shear modulus is estimated using field tests such as seismic down hole or cross hole tests. Cyclic soil behavior is characterized using laboratory tests such as resonant column, cyclic triaxial or simple shear tests. The maximum shear modulus is defined as $\mathrm{G}_{\max }$ and corresponds to the initial shear modulus.
Insitu measurement of $\mathrm{V}_{\mathrm{s}}$ using geophysical methods is the best method for measuring the $\mathrm{G}_{\max }$ (Rolling et al. 1998). Geophysical methods are based on the fact that the velocity of propagation of a wave in an elastic body is a function of the modulus of elasticity, Poisson ratio and density of material (Hvorslev 1949).

By consideration, a uniform soil layer lying on an elastic layer of rock that extends to infinite depth and the subscripts $s$ and $r$ refer to soil and rock, the horizontal displacement due to vertically propagation harmonic $\mathrm{S}$ wave in each material can be written as:

$$
\begin{aligned}
& u_{s}\left(Z_{s}, t\right)=A_{s} e^{i\left(\omega t+K_{s}{ }^{*} Z_{s}\right)}+B_{s} e^{i\left(\omega t-K_{s}{ }^{*} Z_{s}\right)} \\
& u_{r}\left(Z_{r}, t\right)=A_{r} e^{i\left(\omega t+K_{r}{ }^{*} Z_{r}\right)}+B_{s} e^{i\left(\omega t-K_{r}{ }^{*} Z_{r}\right)}
\end{aligned}
$$

$u$ : displacement, $\omega$ : circular frequency of the harmonic wave, $\mathrm{k}^{*}$ : complex wave number

No shear stress can exist at the ground surface $(\mathrm{zs}=0)$, so

$$
\tau_{(0, t)}=G_{s}^{*} \gamma_{(0, t)}=G_{s}{ }^{*} \frac{\partial u_{s}(0, t)}{\partial z_{s}}=0
$$

Where $\mathrm{G}_{\mathrm{s}}{ }^{*}=\mathrm{G}(1+2 \mathrm{i} \xi)$ is the complex shear modulus of the soil. Schnabel et al. (1972) explained that within a given layer (layer $j$ ); the horizontal displacements for two motions (A and B) may be given as:

$$
u_{r}\left(z_{i}, t\right)=\left(A_{i} e^{i k_{i}^{*} z_{i}}+B_{i} e^{-i k_{i}^{*} z_{i}}\right) e^{i \omega t}
$$

Thus, at the boundary between layer $j$ and $j+1$, compatibility of displacements requires that:

$$
A_{j+1}+B_{j+1}=A_{j} e^{i k_{j}{ }^{*} h_{j}}+B_{j} e^{-i k_{j}^{*} h_{j}}
$$

Continuity of shear stresses requires that:

$$
A_{j+1}+B_{j+1}=\frac{G_{j}{ }^{*} k_{j}{ }^{*}}{{G_{j+1}}^{*} k_{j+1}{ }^{*}}\left(A_{j} e^{i k_{j}{ }^{*} h_{j}}-B_{j} e^{-i k_{j}{ }^{*} h_{j}}\right)
$$

The effective shear strain of equivalent linear analysis is computed as:

$$
\begin{gathered}
\gamma_{\text {eff }}=R_{\gamma} \gamma_{\max } \\
R_{\gamma}=\frac{M-1}{10}
\end{gathered}
$$

$\gamma_{\max }$ : maximum shear strain in the layer, $\mathrm{R}_{\gamma}$ : strain reduction factor, $\mathrm{M}$ : magnitude of earthquake

The motion at any layer can be easily computed from the motion at any other layer (e.g. input motion imposed at the bottom of the soil column) using the transfer function that relates displacement amplitude at layer $i$ to that the layer $j$ :

$$
F_{i j}(\omega)=\frac{\left|u_{i}\right|}{\left|u_{j}\right|}=\frac{a_{i}(\omega)+b_{i}(\omega)}{a_{j}(\omega)+b_{j}(\omega)}
$$

The nonlinear hyperbolic model used in this paper was developed by Konder and Zelasko (1963) to model the stress-strain soil behavior of soils subjected to constant rate of loading. The hyperbolic equation is defined as:

$$
\tau=\frac{G_{m o} \gamma}{1+\left(\frac{G_{m o}}{\tau_{m o}} \gamma\right)}=\frac{G_{m o} \gamma}{1+\left(\frac{\gamma}{\gamma_{r}}\right)}
$$

$\tau$ : shear stress, $\gamma$ : shear strain, $\mathrm{G}_{\mathrm{mo}}$ : initial shear modulus, $\tau_{\mathrm{mo}}$ : shear strength, $\gamma_{\mathrm{r}}=\tau_{\mathrm{mo}} / \mathrm{G}_{\mathrm{mo}}$ : reference shear strain

The reference shear strain is strain at which failure would 
occur if soil were to behave elastically. It has been considered a material constant by Hardin and Drnevich (1972). The reference strain can also be represented as function of initial tangent modulus and undrained shear strength in clays (Mersi et al. 1981). The solution of the wave propagation equation is performed in either frequency or time domain (Park and Hashash, 2004). The soil medium is divided into sub layers with absolute displacement $u_{\mathrm{j}}$, defined at $\mathrm{j}^{\text {th }}$ sub layer interface and with shear stress $\tau_{\mathrm{j}}$, defined at the mid points of each interface. As Kramer (1996) explained, the response of soil deposit under dynamic loading is governed by the equation of motion as bellows:

$$
\frac{\partial \tau}{\partial z}=\rho \frac{\partial^{2} u}{\Delta t^{2}}
$$

The differentiation for a soil divided to $\mathrm{N}$ sub layers of thickness $\Delta \mathrm{z}$ and processing for the small time increment $\Delta \mathrm{t}$ is computed by using finite difference method as bellows:

$$
\begin{aligned}
& \frac{\partial \tau}{\partial z}=\frac{\left(\tau_{i+1}-\tau_{i-1}\right)}{\Delta z} \\
& \frac{\partial^{2} u}{\partial t^{2}}=\frac{\left(\dot{u}_{i, t+\Delta t}-\dot{u}_{i, t}\right)}{\Delta t}
\end{aligned}
$$

$\dot{u}=\frac{\partial u}{\partial t}:$ Velocity of the motion, $\frac{\partial^{2} u}{\partial t^{2}}=\frac{\partial \dot{u}}{\partial t}$ : acceleration

The result of the combination the equations 11,12 and 13 will get:

$$
\frac{\left(\tau_{i+1}-\tau_{i-1}\right)}{\Delta z}=\rho \frac{\dot{u}_{i, t+\Delta t}-\dot{u}_{i, t}}{\Delta t}
$$

Moreover, it can be simplified as:

$$
\dot{u}_{i, t+\Delta t}=\dot{u}_{i, t}+\frac{\Delta t}{\rho \Delta z}\left(\tau_{i+1, t}-\tau_{i, t}\right)
$$

As mentioned above, for the soil surface, the shear stress is equal to zero and boundary condition for each sub layer must be satisfied. For soil, rock boundaries Joyner and Chen (1975) proposed the following equation for soil rock boundaries:

$$
\tau_{r, t}=\rho_{r} V_{s r}\left[2 \dot{u}_{r}(t+\Delta t)-\dot{u}_{N+1, t+\Delta t}\right]
$$

By using the equations, 15, 16 the boundary conditions are satisfied. Kramer (1996) proposed the shear for each layer as below:

$$
\gamma_{i, t}=\frac{\partial u_{i, t}}{\partial z} \approx \frac{\left(u_{i+1}-u_{i, t}\right)}{\Delta z}
$$

As above mentioned equations show, the shear stress is computed by using current shear strain and stress-strain history $\left(\tau_{i, t}=G_{i} \gamma_{i, t}\right)$. Thus, the proposed method satisfies the nonlinear and inelastic behavior of soil under earthquake excitation.

\section{Data and Analysis Frame Work}

The selected region is an earth dam with clay core with crest length of $445 \mathrm{~m}$ and width of $10 \mathrm{~m}$. The dam has been built over Cheshmeh Ali River, $12 \mathrm{~km}$ northwest of Damghan city. About 200 billion rials have been invested in the project and 135 billion rials are needed for building irrigation and drainage network of the dam. The dam is to control floods and save surplus agricultural water to increase area of farmlands by 1,500 hectares. This dam is located in $54^{\circ} 14^{\prime} 31^{\prime \prime}$ East longitude and $36^{\circ} 13^{\prime} 50^{\prime \prime}$ North latitude. The other characteristics of this dam are given in table (1). The oldest rock outcrops in this region belongs to Barut formation and the others belong to recent sediment and deposits. The lithology of the selected site is a combination of limestone, dolomite, shale parts, dark red sandstones, volcanic portions, pink marl, white quartzite and conglomerate unit. In seismotectonic point of view, according to recent classification, the target area is near and beside the intersection of the Alborz-Kopedagh and Central Iran seismotectonic provinces.

Table 1. characteristics of Damghan earth dam

\begin{tabular}{|c|c|}
\hline Property & Quantity \\
\hline Height & $\begin{array}{c}51.5 \mathrm{~m} \text { (from the bed) and } 54.5 \mathrm{~m} \text { (from the } \\
\text { foundation) }\end{array}$ \\
\hline Effective capacity & $12.8 \mathrm{Mm}^{3}$ \\
\hline Total capacity & $21 \mathrm{Mm}^{3}$ \\
\hline Lake area & $1.5 \mathrm{Km}^{2}$ \\
\hline
\end{tabular}

The analysis program is pointed in figure 2. As indicated, at the first step the field and laboratory test were conducted and then the drilled boreholes were investigated. A total of 23 drilled boreholes with maximum depth of $125 \mathrm{~m}$ were drilled in the selected site to investigate the geotechnical characteristics of the subsurface layers of the dam area and their results with statistical analysis are indicated in tables (2), (3), (4) and (5).

In this step, the site characterized and the condition of subsurface layers was determined. By Collected and obtained data from the previous step the idealized soil profile for the studied area was determined and the $\mathrm{L}$ component of Kahak earthquake with magnitude of 5.7, which happened in Iran (2007), was applied to idealized constructed soil profile of the area. To compute the surface parameters, the authors would be forced to combine several software packages with the generated GUI computer code named as "Abbas Converter V2.01" (figure3) that is written with C Sharp Computer language and it is the developed version of old ones which was introduced by Abbaszadeh Shahri et al., (2009). By the generated code, it is possible to take over the encountered problem and by this code the calculated output parameters such as motion, surface response, spectral acceleration, stress, strain and PGA profile for rigid and elastic half space bedrock were computed and compared to each other as shown in figure 4 and 5. To modify and validate the applied method in this study the damping ratio and shear stress reduction curve of the investigated area was computed and compared by several known curves. As shown in figure

$6,7,8$ and 9 the computed curves have a good agreement 
with others and this point can certify the validation of the study. For better understand the numerical analysis of this study was indicated in table (6).

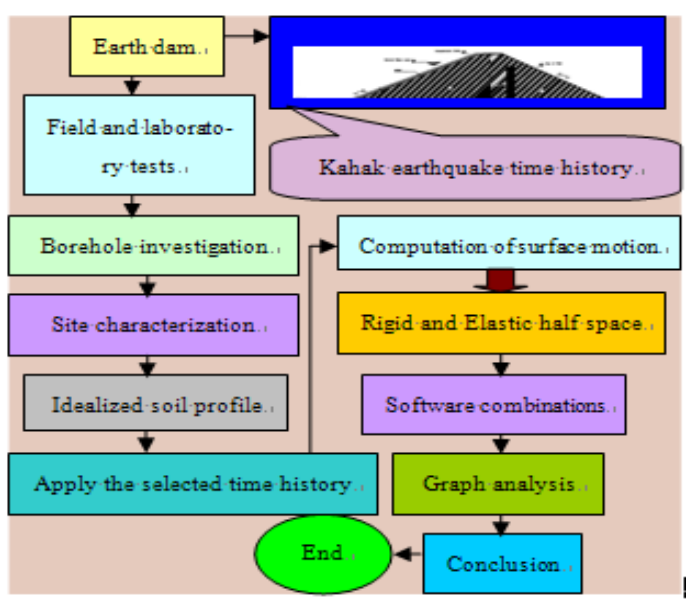

Figure 2. Summarized analysis frame work in this study

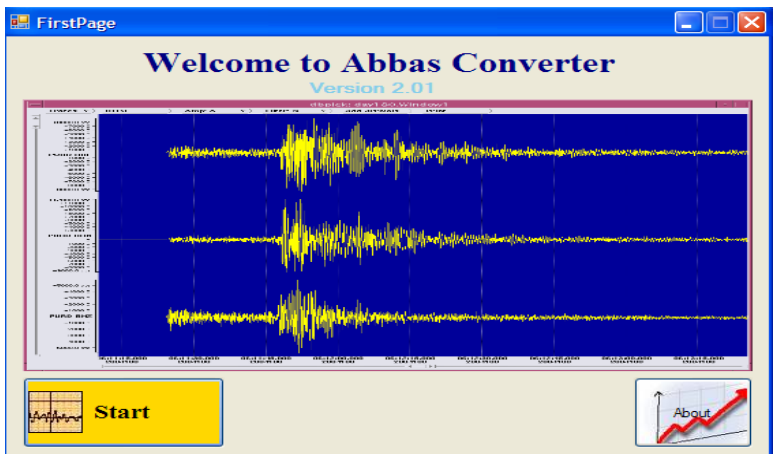

Figure 3. Start screen of generated computer code

Table 2. drilled boreholes with their location in the investigated site

\begin{tabular}{|c|c|c|c|c|}
\hline \multirow{2}{*}{ borehole } & \multicolumn{2}{|c|}{ Coordination } & \multirow{2}{*}{ depth } & \multirow{2}{*}{ location } \\
\cline { 2 - 3 } & X -25 & Y -401 & & \\
\hline BH1 & 3047.7 & 2555.9 & 100 & River bed \\
\hline BH1-1 & 3008.12 & 2600.66 & 100 & River bed \\
\hline BH1-2 & 3096.67 & 2530.77 & 100 & River bed \\
\hline BH2 & 3116.47 & 2660.90 & 100 & Left bank \\
\hline BH3 & 3169.91 & 2690.93 & 100 & Left bank \\
\hline BH4 & 3308.94 & 2822.88 & 60 & Left bank \\
\hline BH5 & 3060.98 & 2572.14 & 60 & River bed \\
\hline BH6 & 3022.32 & 2529.42 & 125 & Right bank \\
\hline BH7 & 2632.05 & 2238.09 & 100 & Right bank \\
\hline BH8 & 2944.84 & 2517.04 & 100 & Right bank \\
\hline BH9 & 2874.95 & 2705.44 & 100 & Left bank \\
\hline BH10 & 2963.65 & 2767.24 & 100 & Left bank \\
\hline BH11 & 3255.15 & 2468.86 & 100 & Right bank \\
\hline TUA1 & 2620.06 & 2695.00 & 60 & Tunnel line \\
\hline TUA2 & 2951.23 & 2426.44 & 50 & Tunnel line \\
\hline TUA3 & 3181.39 & 2282.41 & 60 & Tunnel line \\
\hline TUA4 & 2810.07 & 2657.73 & 40 & Tunnel line \\
\hline NS2 & 3385.14 & 3064.00 & 40 & Near spillway \\
\hline NS3 & 3654.16 & 2729.94 & 40 & Near spillway \\
\hline
\end{tabular}

Table 3. statistical analysis of rock quality designation of the left support of the dam

\begin{tabular}{|c|c|c|c|c|c|c|}
\hline \multirow{2}{*}{$\begin{array}{c}\text { Standard } \\
\text { deviation }\end{array}$} & \multirow{2}{*}{ Variation } & \multicolumn{3}{|c|}{ RQD(Ave) } & \multirow{2}{*}{ depth(m) } & \multirow{2}{*}{ borehole } \\
\cline { 3 - 6 } & & $\max$ & $\min$ & Ave & & \\
\hline 26.19 & 685.76 & $84 \%$ & $0 \%$ & $38 \%$ & 85 & BD5 \\
\hline 5.35 & 28.7 & $94 \%$ & $83 \%$ & $86 \%$ & 25 & BD4 \\
\hline--- & --- & $63 \%$ & $38 \%$ & $53 \%$ & 25 & BD6 \\
\hline 26.6 & 706 & $98 \%$ & $0 \%$ & $74 \%$ & 100 & BH2 \\
\hline 27.3 & 743.8 & $84 \%$ & $0 \%$ & $39 \%$ & 100 & BH3 \\
\hline 15.2 & 229.54 & $85 \%$ & $39 \%$ & $66 \%$ & 60 & BH4 \\
\hline 13.2 & 173.42 & $97 \%$ & $52 \%$ & $76 \%$ & 60 & BH5 \\
\hline 21.8 & 473.3 & $83 \%$ & $2 \%$ & $35 \%$ & 100 & BH10 \\
\hline 22.8 & 518.6 & $90 \%$ & $22 \%$ & $73 \%$ & 40 & NS2 \\
\hline 28.5 & 810.3 & $97 \%$ & $19 \%$ & $72 \%$ & 40 & NS3 \\
\hline 24.13 & 582.3 & $88 \%$ & $26 \%$ & $57 \%$ & --- & $\begin{array}{r}\text { left } \\
\text { support }\end{array}$ \\
\hline
\end{tabular}

Table 4. statistical analysis of rock quality designation of the dam foundation

\begin{tabular}{|c|c|c|c|c|c|}
\hline \multirow{2}{*}{$\begin{array}{c}\text { Standard } \\
\text { deviation }\end{array}$} & \multirow{2}{*}{ Variation } & \multicolumn{3}{|c|}{ RQD (\%) } & \multirow{2}{*}{ borehole } \\
\cline { 3 - 6 } & & max & min & Ave & \\
\hline 31.5 & 992.9763 & 91 & 0 & 44 & BH9 \\
\hline 18 & 322.74 & 99 & 43 & 72 & BH(1-1) \\
\hline 16.15 & 272.3026 & 100 & 50 & 79 & BH1 \\
\hline 14.2 & 201.3132 & 94 & 29 & 74 & BH(1-2) \\
\hline 26.42 & 697.87 & 95 & 2 & 58 & BH11 \\
\hline 22.3 & 497.44 & 96 & 25 & 65 & foundation \\
\hline 25.91 & 671.195 & 95 & 15 & 58 & $\begin{array}{c}\text { Upper Miocene } \\
\text { conglomerate }\end{array}$ \\
\hline 15.4 & 236.81 & 97 & 40 & 77 & Elica limes \\
\hline
\end{tabular}

Table 5. statistical analysis of rock quality designation of the right support of the dam

\begin{tabular}{|c|c|c|c|c|c|}
\hline \multirow{2}{*}{$\begin{array}{l}\text { Standard } \\
\text { deviation }\end{array}$} & \multirow{2}{*}{ Variation } & \multicolumn{3}{|c|}{ RQD(\%) } & \multirow{2}{*}{ borehole } \\
\cline { 3 - 5 } & & $\max$ & $\min$ & Ave & \\
\hline 31 & 959.4103 & 95 & 0 & 51 & BD2 \\
\hline 26.6 & 706.1554 & 95 & 9 & 54 & BD3 \\
\hline 23.85 & 568.59 & 100 & 22 & 66 & BH6 \\
\hline 30.44 & 926.85 & 100 & 10 & 57 & BH8 \\
\hline 19.2 & 367.32 & 94 & 27 & 52 & BD1 \\
\hline 29.63 & 878.0227 & 93 & 0 & 72 & TUA1 \\
\hline 13.44 & 180.7 & 72 & 31 & 54 & TUA2 \\
\hline 20.7 & 427.61 & 59 & 3 & 37 & TUA3 \\
\hline 26 & 663.9821 & 59 & 30 & 68 & TUA4 \\
\hline 17.5 & 305.757 & 94 & 24 & 81 & BH7 \\
\hline 4.7 & 22.1 & 99 & 82 & 90 & BD7 \\
\hline 23.5 & 552.25 & 93 & 18 & 61 & $\begin{array}{c}\text { Right } \\
\text { support }\end{array}$ \\
\hline 26.5 & 702.6 & 97 & 13 & 56 & $\begin{array}{c}\text { Around } \\
\text { the dam } \\
\text { body }\end{array}$ \\
\hline & & & & & \\
\hline
\end{tabular}




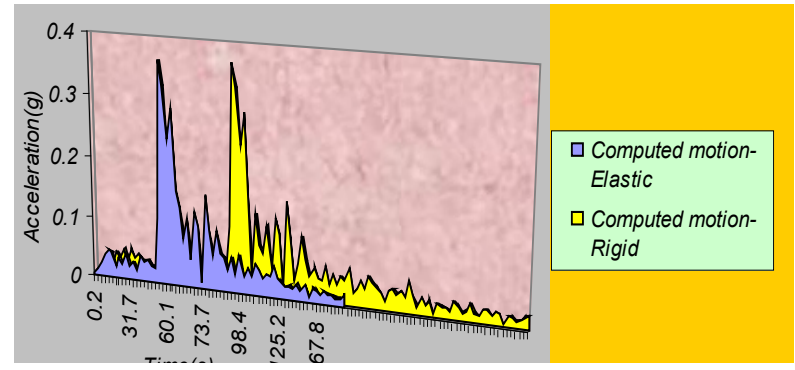

Figure 4. Comparison between elastic and rigid half space computed time history

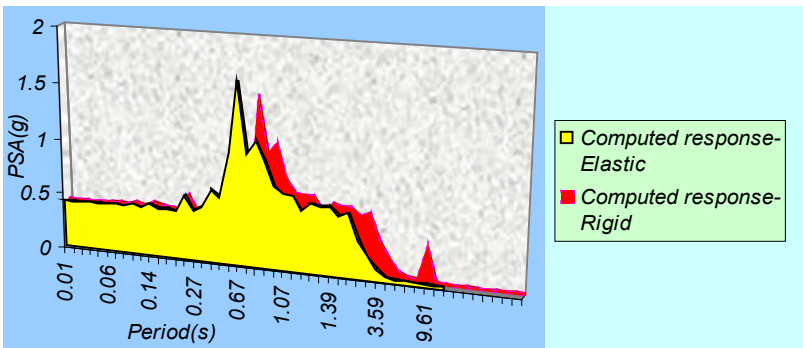

Figure 5. Comparison between elastic and rigid half space computed response spectra

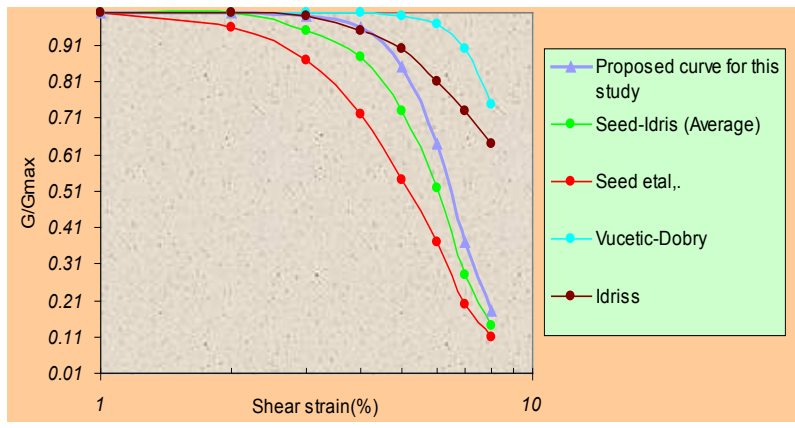

Figure 6. Comparison of obtained shear modulus curve with known ones

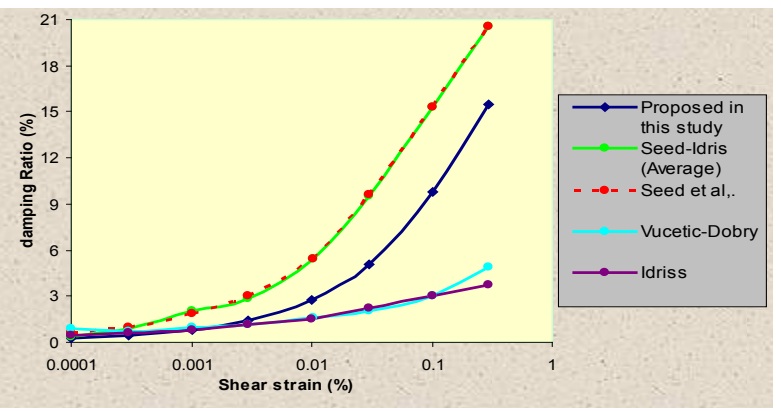

Figure 7. Comparison of obtained damping ratio curve with known one

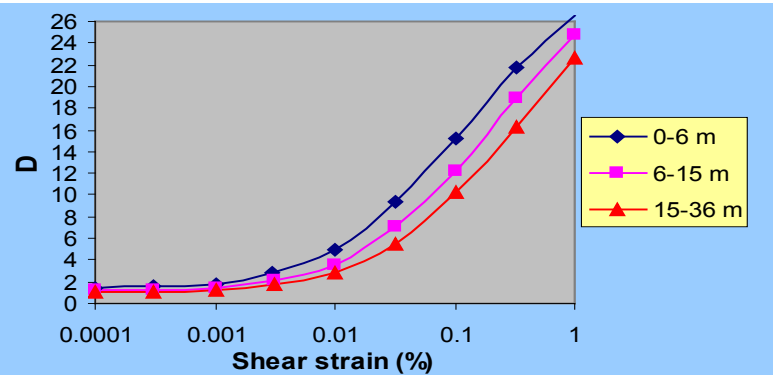

Figure 8. Computed shear modulus curve for various depth of idealized soil profile

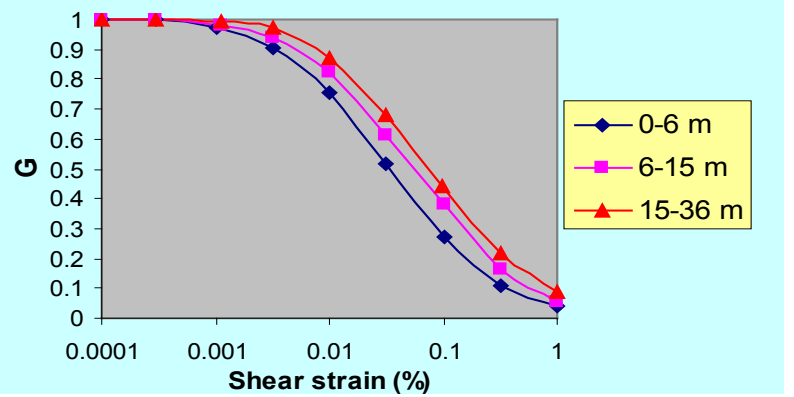

Figure 9. Computed damping ratio curve for various depth of idealized soil profile

Table 6. numerical computed results of this study for the selected site

\begin{tabular}{|c|c|c|c|}
\hline $\begin{array}{c}\text { Computed on } \\
\text { surface }\end{array}$ & Input & condition & parameter \\
\hline $1.629 \mathrm{~g}(0.67 \mathrm{~s})$ & $1.586 \mathrm{~g}(0.67 \mathrm{~s})$ & Elastic & \multirow[t]{2}{*}{ response } \\
\hline $1.634 \mathrm{~g}(0.67 \mathrm{~s})$ & $1.588 \mathrm{~g}(0.67 \mathrm{~s})$ & Rigid & \\
\hline $0.1542 \%(59 \mathrm{~s})$ & $\begin{array}{c}0.000866 \%(59 \mathrm{~s} \\
)\end{array}$ & Elastic & \multirow[b]{2}{*}{ Strain } \\
\hline $0.1664 \%(59 \mathrm{~s})$ & $\begin{array}{c}0.000875 \%(59 \mathrm{~s} \\
)\end{array}$ & Rigid & \\
\hline $\begin{array}{c}10.18(13.82 \mathrm{~Hz} \\
)\end{array}$ & - & Elastic & \multirow{2}{*}{$\begin{array}{c}\text { Amplification } \\
\text { factor }\end{array}$} \\
\hline $\begin{array}{c}15.65(13.74 \mathrm{~Hz} \\
)\end{array}$ & ----- & Rigid & \\
\hline $1.609 \mathrm{~g}(0.67 \mathrm{~s})$ & - --- & Elastic & \multirow{2}{*}{$\begin{array}{c}\text { Spectral } \\
\text { acceleration }\end{array}$} \\
\hline $1.604 \mathrm{~g}(0.66 \mathrm{~s})$ & ---- & Rigid & \\
\hline$-0.429 \mathrm{~g}(59 \mathrm{~s})$ & $-0.389 \mathrm{~g}(59 \mathrm{~s})$ & Elastic & \multirow[t]{2}{*}{ motion } \\
\hline$-0.431 \mathrm{~g}(59 \mathrm{~s})$ & $-0.39 \mathrm{~g}(59 \mathrm{~s})$ & Rigid & \\
\hline $1.07(59 \mathrm{~s})$ & $0.654(59 \mathrm{~s})$ & Elastic & \multirow{2}{*}{ stress } \\
\hline $1.111(59 \mathrm{~s})$ & $0.66(59 \mathrm{~s})$ & Rigid & \\
\hline $0.589(0.63 \mathrm{~Hz})$ & $0.63(0.586 \mathrm{~Hz})$ & Elastic & \multirow{2}{*}{$\begin{array}{c}\text { Fourier } \\
\text { amplitude }\end{array}$} \\
\hline $0.59(0.63 \mathrm{~Hz})$ & $0.586(0.63 \mathrm{~Hz})$ & Rigid & \\
\hline $66.5(11.99 \mathrm{~Hz})$ & $2.106(11.99 \mathrm{~Hz})$ & Elastic & \multirow{2}{*}{$\begin{array}{c}\text { Fourier } \\
\text { amplitude ratio }\end{array}$} \\
\hline $80.1(11.99 \mathrm{~Hz})$ & $22.48(26.16 \mathrm{~Hz})$ & Rigid & \\
\hline
\end{tabular}

\section{Conclusions and Discussion}

This study tried to follow in conducting a meaningful nonlinear site response and amplification study. After evaluating the accelerograms at the bedrock, the ground response analysis at the surface, in terms of time history and response spectra, has been obtained by nonlinear standard hyperbolic model and authors have been trying to find a practical and appropriate solution for ground response analysis under earthquake forces for the selected site. For achieve to this aim, a user graphical interface software was produced and developed by authors and on base of this generated code, a new practical reliability geotechnical based method procedure has been presented. To validate of this code and to prove the accuracy and capability of the proposed procedure, a case study on ground response analysis of a site in Damghan earth dam in Semnan province of Iran, during the Kahak earthquake (2007) is executed. This study shows that this generated computer code can be applied as a strong and reliable tool for future. The obtained 
results in this study shows a good agreement by known applicable procedures where as in modulus degradation can recognized between back calculation and some of previous laboratory test results for soils in the site of dam. Distribution of maximum acceleration along the depth and spectrum ratios has proved that rigid half space bedrocks compute larger peak accelerations. The PGA value at the ground surface obtained from the generated computer code can use to prepare the PGA map of selected site. They are not distributed uniformly due to variation in the soil profile at various locations. More that this PGA is comparable to obtained peak horizontal acceleration values using SPT data and the shape of variation of peak acceleration with depth are similar to the SPT data. The calculated amplification factor ranged in elastic and rigid condition can be used to prepare the amplification map of Damghan earth dam.

\section{REFERENCES}

[1] A.A.Shahri, Esfandiyari, B. and Hamzeloo, H., 2009, A comparative case study on time domain nonlinear site response analysis subjected to earthquake excitation with elastic and rigid half space (site of damghan earth dam-Semnan province-Iran), Scientific Research and Essay, Vol. 4 (7): 665-676.

[2] Abbaszadeh shahri, A., Esfandiyari, B. and Hamzeloo, H., 2009, Evaluation of a nonlinear seismic geotechnical site response analysis method subjected to earthquake vibrations (case study:Kerman province, Iran)", Arabian Journal of Geosciences, Springer, accepted in 14 December 2009, in print.

[3] Aguirre, J., K. Irikura, and K. Kudo., 1994, Estimation of strong ground motion on hard rock and soft sediment sites in Ashigara valley using the empirical Green's function method, Bull. Disast. Prev. Res. Inst., Kyoto Univ. 44, 45-68.

[4] Aki, K. 1993, Local site effects on weak and strong ground motion, Tectonophysics, 218, 93-111.

[5] Ambraseys, N.N., Melville, C, P., 2005, A History of Persian Earthquakes, Published by Cambridge University Press, 240 pages.

[6] Beresnev, I.A., 2002, Nonlinearity at California generic soil sites from modeling recent strong-motion data, Bull. Seism. Soc. Am., 92, 863-870.

[7] Berberian, M., 1977, Macroseismic Epicentres of Iranian Earthquakes, Geological and Mining of Iran, 40, 79-99.

[8] Bonilla, L. F, R. Archuleta, and D. Layalee., 2005, Hysteretic and dilatant behavior of cohesionless soils and their effects on nonlinear site response: field data observations and modeling, Bull. Seism. Soc. Am. (Accepted for publication)

[9] Borcherdt, R.D., 1970, Effects of local geology on ground motion near San Francisco Bay, Bull. Seism. Soc. Am. 60, 29-61.

[10] Dehghani, G.A., Makris, J., 1983, The gravity field and crustal structure of Iran. Geodynamics Project (Geotraverse) in Iran, Geological Survey of Iran, Rep. No. 51, 51-68.

[11] Field, E. H., P. A. Johnson, I. A. Beresnev, and Y. Zeng., 1997, Nonlinear ground-motion amplification by sediments during the 1994 Northridge earthquake, Nature, 390, 599-602.

[12] Field, E. H., S. Kramer, A.-W. Elgamal, J.D. Bray, N. Matasovic, P.A. Johnson, C. Cramer, C. Roblee, D. J. Wald, L.F. Bonilla, P.P. Dimitriu, and J.G. Anderson.,1998, Nonlinear site response: Where we're at. Proceedings of the VIIth International Symposium on the Observations of the Continental Crust through Drilling 69, no3.

[13] Hardin BO, Drenvich VP, 1972, Shear modulus and damping in soils: measurement and parameter effects. Journal of Soft Mechanics and Foundation Division, 98 (SM6), 603-624.

[14] Hvorslev MJ, 1949, Subsurface exploration and sampling ofsoils for civil engineering purposes. Waterway Experiment Station, Vicksburg, Missisippi, p.521.

[15] Idriss, I.M., 1991, Earthquake ground motions at soft soil sites, Special Session in Honor of H.B. Seed, Proc. Second Int. Conf. on Recent Advances in Geotech. Earthq. Eng. and Soil Dyn., St. Louis.

[16] Iwasaki, Y. and Tai, M., 1996, Strong motion records at Kobe Port Island, Special Issue of Soils and Foundations, V1, $29-40$.

[17] Konder, RL and Zelasko JS, 1963, Hyperbolic stress-strain formulation of sands, Second Pan American conference on soil mechanics and foundation engineering, Saopaulo, Brazil, pp289-324.

[18] Kramer SL., 1996, Geotechnical earthquake engineering. in prentice -Hall international series in civil engineering and engineering mechanics, Prentice-Hall, New Jersey.

[19] Mersi G, Febres-Cordero E, Sheilds DR, Castro A, 1981. Shear stress-strain -time behavior of clays. Geotechinique, 31(4), 537-552.

[20] Midorikawa, S., 1993, Nonlinearity of site amplification during strong ground shaking, Zishin. 207-216 (English abstract) Park D, Hashash YMA, 2004, Soil damping formulation in nonlinear time domain site response analysis, J. Earthquake Eng. 8 (2): 249-274.

[21] Rolling KM, Evans MD, Diehl NB, Daily WD ,1998, Shear modulus and damping relationships for gravel. J. Geotech. Geoenv. Engg., ASCE 124, 396-405.

[22] Schnabel PB, Lysmer J, Seed HB, 1972, SHAKE: a computer program for earthquake response analysis of horizontally layered sites, Report No. EERC72-12, University of California, Berkeley.

[23] Seed HB, Idriss IM, 1970, soil moduli and damping factors for dynamics response analysis, Report No. EERC70-10, University of California, Berkeley 